\title{
UJI KADAR AIR, ABU DAN KARBOHIDRAT PADA SAGU IKAN CAKALANG
} DI KABUPATEN PULAU MOROTAI

\section{THE ASSAY OF WATER, ASH, AND CARBOHYDRATE CONTENT OF CAKALANG SAGO AT MOROTAI ISLANDS}

\author{
${ }^{1}$ Titien Sofiati, ${ }^{2}$ Asyari, ${ }^{3}$ Jana Sidin \\ 1,2,3Program Studi Teknologi Hasil Perikanan, Fakultas Perikanan dan Ilmu Kelautan Universitas \\ Pasifik Morotai Jalan. Siswa Darame, Kecamatan Morotai Selatan Kabupaten Pulau Morotai, Maluku Utara
}

Korespondensi : titian_sofiati@yahoo.com

\begin{abstract}
ABSTRAK
Sagu ikan merupakan hasil diversifikasi produk perikanan yang menggabungkan panganan tradisional dengan salah satu sumberdaya ikan lokal. Penambahan ikan pada bahan utama sagu yakni ubi kayu diharapkan dapat meningkatkan kandungan gizi sehingga dapat menjadi suatu produk olahan yang bernilai ekonomis. Tujuan penelitian adalah untuk mengetahui kandungan air, abu dan karbohidrat pada sagu ikan. Manfaat yang diharapkan dari penelitian ini adalah (1) memberikan informasi bagi masyarakat tentang pengolahan sagu yang ditambahkan daging ikan cakalang memiliki nilai gizi yang cukup lengkap, (2) diversifikasi dan pengembangan produk perikanan yang baru yang memiliki nilai ekonomis penting untuk masyarakat luas, baik instansi pemerintah maupun swasta yang berkecimpung dalam usaha pembuatan sagu ikan. Penelitian dilaksanakan di Laboratorium Lingkungan Universitas Khairun Ternate. Hasil uji laboratorium menunjukan bahwa penambahan ikan cakalang pada sagu menurunkan kadar air 11,21\% menjadi $10,66 \%$, karbohidrat 70,40\% menjadi $60,43 \%$. Namun, menaikan kadar abu yang terkandung pada sagu ikan $0,98 \%$ menjadi $1,80 \%$.
\end{abstract}

Kata kunci : Sagu ikan, diversifikasi, kandungan gizi

\begin{abstract}
Fish Sago is the result of diversification fishing product that combined between traditional foods with one of the local fish source. The addition of fish to the main material sago, which is cassava, be supposed to increase the nutrition, as the result can be a product with economic values.the purpose of research is to know the level of water, dust, and carbohydrate of fish sago. The significance that expected from this research is (1) giving information to public about the processing of sago with Cakalang can give a complete enough nutrition, (2) diversification and cultivation of the new fish product with high economic value to society, right from public or private institute that work to make fish sago. The research take a place at Environment Laboratory of Khairun University Ternate (Laboratorium Lingkungan Universitas Khairun Ternate). The laboratory's test result showed that the addition of Cakalang to Sago can decrease the water level from $11,21 \%$ to $10,66 \%$, carbohydrate from 70,40\% to 60,43\%. However, the level of dust got increase from 0,98\% to $1,80 \%$.
\end{abstract}

Keywords : fish sago, diversification, nutrition

\section{PENDAHULUAN}

Ikan merupakan sumber protein utama masyarakat Indonesia dan khususnya di Maluku Utara. Ikan dikonsumsi oleh masyarakat Maluku Utara dalam bentuk ikan segar, 
ikan olahan (ikan asap, ikan garam, dan lain-lain), maupun ikan hasil diversifikasi produk. Salah satu produk diversifikasi yang memanfaatkan produk lokal dengan ikan yaitu sagu ikan.

Sagu yang merupakan makanan tradisional masyarakat Maluku Utara merupakan olahan batang pohon sagu dan ubi kayu. Khusus untuk Kabupaten Pulau Morotai sagu dibuat berbahan baku ubi kayu. Namun, karena hanya berbahan baku ubi kayu produk ini memiliki nilai gizi yang relative rendah. Ikan yang menjadi bahan tambahan pada sagu dalam penelitian ini adalah ikan cakalang (Katsuwonus pelamis) yang kaya akan kandungan gizi. Sunahwati (2000), mengemukakan bahwa komposisi kimia ikan cakalang yaitu 21,87\% kadar air, 67,33\% protein, dan 4,16\% lemak. Oleh karena itu diharapkan dengan penambahan ikan cakalang dapat meningkatkan kandungan gizi pada sagu ikan.

Sofiati et al., (2020) mengemukakan bahwa penambahan daging ikan cakalang memberi pengaruh pada kandungan gizi sagu. Kandungan protein pada sagu ikan memiliki kandungan protein yang lebih besar dibandingkan dengan sagu yang belum ditambah dengan ikan cakalang. Namun, pada penelitian tersebut hanya melihat kandungan protein dan lemak pada sagu ikan. Kandungan gizi penting lainya tidak dilihat. Oleh karena itu dilakukan penelitian ini dengan tujuan untuk melihat kandungan gizi (air, abu, dan karbohidrat) pada sagu ikan cakalang di Kabupaten Pulau Morotai.

\section{METODE PENELITIAN}

\section{Lokasi Penelitian}

Penelitian dilaksanakan melalui dua tahap pada bulan September sampai Oktober 2019. Pembuatan sampel sagu ikan pada tahap pertama penelitian dilakukan di Desa Dehegila Kecamatan Morotai Selatan. Sedangkan tahap kedua penelitan meliputi pengujian gizi sagu ikan di Laporatorium Lingkungan Universitas Khairun Ternate.

\section{Alat dan bahan}

1) Alat pembuatan sagu Ikan 
Alat yang digunakan pada pembuatan sampel sagu adalah mesin parut, mesin pengepres, wajan, karung, ayakan, baskom, loyang, timbangan, letakan sagu, forno, kulit jagung, papan penutup forno, dan jepitan sagu.

2) Alat uji kadar air, abu, dan karbohidrat

Alat yang digunakan dalam uji proksimat adalah cawan porselen, oven, desikator, timbangan analitik, mortar, tang penjepit, tanur, labu takar $100 \mathrm{ml}$, Erlenmeyer, kertas saring, Soxhlet, dan labu kjeldahl.

3) Bahan

Bahan yang digunakan dalam penelitian ini yaitu sampel produk sagu lempeng. Adapaun formulasi bahan terlihat pada formulasi berikut:

$\mathrm{A}_{\mathrm{o} .:}$ Kontrol 100\% sagu berbahan dasar ubi kayu

A1 :34\% ikan $+64 \%$ Pati ubi kayu $+16 \%$ penyedap rasa $+04 \%$ lada

\section{Prosedur Penelitian}

1) Proses pembuatan sampel sagu

Pembuatan sampel sagu dilakukan secara bertahap yang terdiri dari bahan baku pembuatan sampel. Tahap pembuatan pati sagu untuk dijadikan bahan baku utama dalam pembuatan sampel sagu lempeng dengan penambahan daging ikan cakalang dapat dilihat pada bagan alur berikut : 


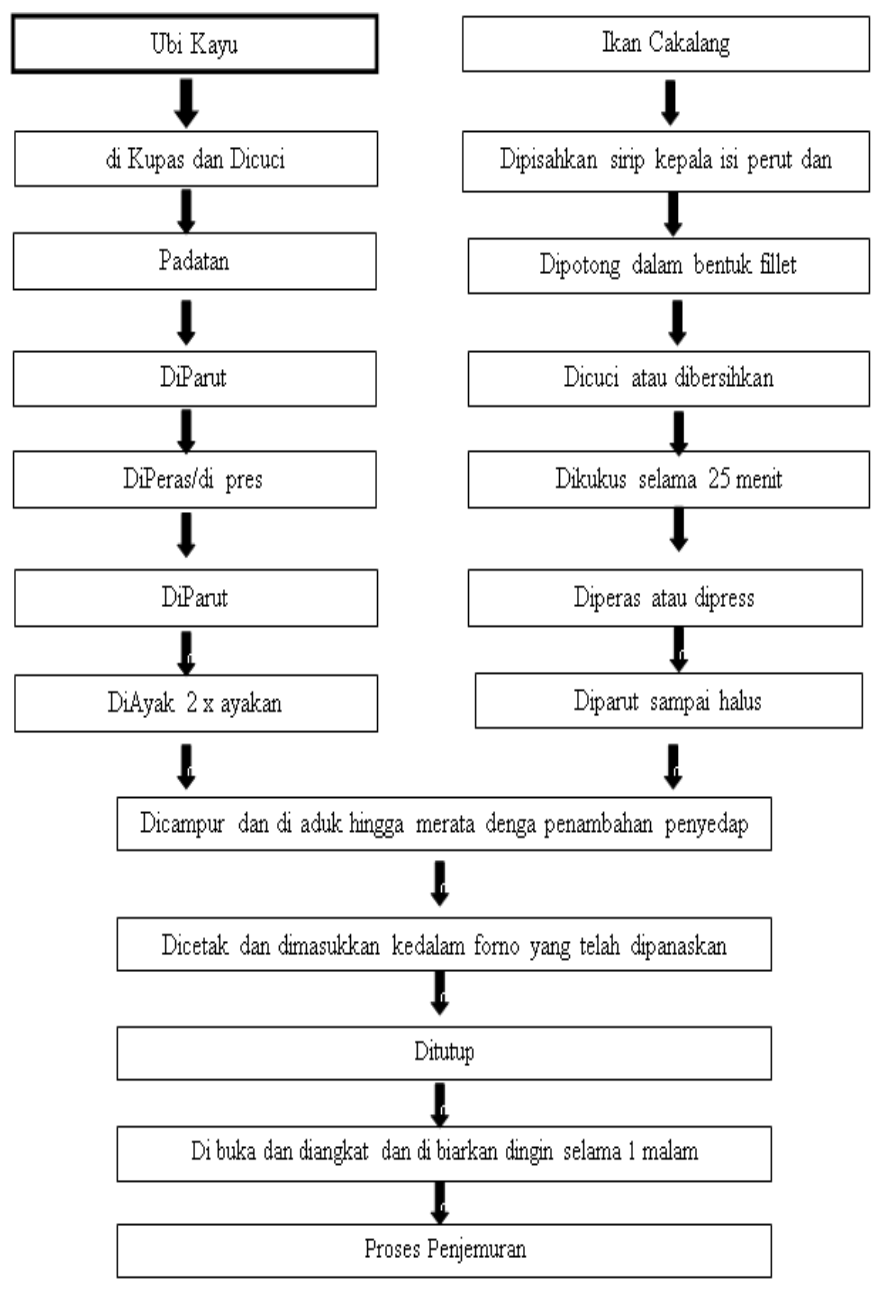

Gambar 1. Alur pembuatan sagu ikan.

\section{2) Kadar air}

Pengujian kadar air menggunakan metode gravimetri (pengerngan dengan oven). Cawan porselen kosong dikeringkan dalam oven selama 15 menit, lalu didingingkan dalam desikator, dan ditimbang. Sebanyak 4-5 g sampel sagu dikeringkan dalam oven pengering pada suhu $10{ }^{\circ} \mathrm{C}$ selama 6 jam. Cawan dengan isinya kemudian didinginkan dalam desikator kemudian ditimbang. Pengeringan dilakukan kembali hingga diperoleh berat konstan. Kadar air dihitung berdasarkan kehilangan berat selisih berat awal sampel sebelum dikeringkan dengan berat akhir setelah dikeringkan.

Kadar air $(\%)=$ berat awal - berat akhir $\times 100 \%$ berat akhir

\section{Berat sampel}


3) Kadar abu

Pengujuan kadar abu mengacu pada metode AOAC (2005). Cawan porselen dipanaskan dalam oven selama 15 menit, lalu didingingkan dalam desikator, dan ditimbang sebanyak 3- 5 g sampel dimasukan dalam cawan porselen dan ditimbang, lalu dibakar sampai tidak berasap lagi dan diabukan dalam tanur $550{ }^{\circ} \mathrm{C}$ sampai berwarna putih (semua sampel menjadi abu) dan beratnya konstan. Setelah itu didinginkan dalam desikator dan ditimbang.

Kadar abu $(\%)=$ berat abu $\times 100 \%$ berat sampel

4) Kadar karbohidrat

Kadar karbohidrat dihitung dengan mengacu pada (Apriantono. 1988) rumus :

Kadar karbohidrat $(\% \mathrm{KH})=100 \%-(\mathrm{A}+\mathrm{B}+\mathrm{C}+\mathrm{D}+\mathrm{E})$

Keterangan $\mathrm{A}=$ Kadar air, $\mathrm{B}=$ kadar $\mathrm{abu}, \mathrm{C}=$ kadar protein, $\mathrm{D}=$ kadar karbohidrat, $\mathrm{E}=$ kadar lemak.

\section{HASIL DAN PEMBAHASAN}

\section{Perbandingan Nilai Gizi Sagu Ikan}

Penelitian dilakukan untuk melihat kandungan gizi (air, abu dan karbohidrat) pada sagu sebelum dan setelah diberi penambahan daging ikan cakalang (Katsuwonus pelamis). Hasil pengujian di Laboratorium Lingkungan Universitas Khairun Ternate kadar air, abu, dan karbohidrat pada sampel penelitian yang terdiri dari Ao (sagu lempeng) dan $\mathrm{A}_{1}$ (sagu ikan) dapat dilihat dalam Tabel 1.

Tabel 1. Hasil analisis nilai gizi sagu ikan

\begin{tabular}{|c|c|c|c|}
\hline \multirow{2}{*}{ No } & \multirow{2}{*}{ Analisis } & \multicolumn{2}{|c|}{ Nilai Gizi (\%) } \\
\hline & & Ao & $A_{1}$ \\
\hline 1. & Kadar Air & 11,21 & 10,66 \\
\hline 2. & Kadar Abu & 0,98 & 1,80 \\
\hline 3. & Kadar Karbohidrat & 70,40 & 60,43 \\
\hline
\end{tabular}

Pada Tabel 1 menunjukkan bahwa terdapat perbedaan kandungan gizi pada sagu lempeng sebelum dan setelah ditambahkan daging ikan. Penambahan daging ikan 
cakalang menambah kadar abu 0,98\% menjadi 1,80\%. Namun, kadar air dan karbohidrat justru mengalami penurunan. Sofiati et al., (2020), mengemukakan bahwa penambahan daging ikan cakalang meningkatkan kadar protein $1,78 \%$ menjadi $15,40 \%$ serta menurunkan kadar lemak 3,13\% menjadi 1,31\%.

\section{Kadar Air}

Kandungan air dalam bahan pangan menentukan penerimaan, dan kesegaran serta daya tahan bahan pangan tersebut (Winarno, 2008). Penambahan daging ikan cakalang pada sagu menurukan kadar air sebesar $0,55 \%$. Perbedaan kadar air yang terjadi sebagian besar dipengaruhi oleh proses penjemuran pada masing-masing perlakuan. Kadar air produk juga dapat dipengaruhi oleh kadar air awal bahan bakunya (Pratama et al., 2013). Ketebalan bahan pangan dan lamanya pengeringan juga sangat berpengaruh terhadap bahan pangan dengan hasil yang diperoleh (Mukhsinatunisa, 2013).

\section{Kadar Abu}

Kadar Abu adalah zat organik dari sisa hasil pembakaran suatu bahan organik. Penentuan kadar abu ada hubungannya dengan mineral suatu bahan pangan (Sudarmadji et al., 1997). Semakin besar kadar abu suatu bahan makanan, menunjukan semakin tinggi mineral yang dikandung oleh makanan tersebut (Ningrum, 1999). Hasil pengujian menunjukan bahwa kadar abu pada sagu yang ditambahkan ikan bertambah dari $0.98 \%$ menjadi $1,80 \%$. Peningkatan kadar abu sagu disebabkan oleh kadar abu bahan pengisi dalam hal ini adalah ikan cakalang. Hal ini sesuai dengan penjelasan dari Mahmud et al. (2008) yang mengemukanan bahwa bahan baku dan bahan pendukung dapat mempengaruhi kadar abu produk makanan yang dihasilkan.

\section{Kadar Karbohidrat}

Karbohidrat merupakan zat gizi penting dalam kehidupan manusia karena berfungsi sebagai sumber energi utama manusia. Karbohidrat dapat memenuhi 60-70\% kebutuhan energi tubuh (Winarno, 2008). Sumber karbohidrat utama pada produk sagu berasal dari 
kandungan karbohidrat pati sagu. Sehingga pada sagu ikan, bahan baku pati sagu sudah mengalami penambahan daging ikan cakalang menyebabkan penurunan kadar karbohidrat. Berdasarkan hasil penelitian, kadar karbohidrat pada sagu ikan 70,40\% turun menjadi 60,43\%. Berkurangnya kadar karbohidrat pada sagu ikan dipengaruhi oleh kandungan gizi lain. Sugito dan Hayati (2006) mengemukakan bahwa semakin rendah kandungan nutrisi/gizi lain makan kandungan karbohidratnya semakin tinggi begitupun sebaliknya. Penambahan ikan cakalang tidak hanya meningkatkan kandungan abu tetapi juga meningkatkan kandungan protein pada sagu ikan (Sofiati et al., 2020).

\section{KESIMPULAN DAN SARAN}

Berdasarkan hasil penelitian dapat disimpulkan bahwa penambahan ikan cakalang pada sagu ikan meningkatkan kadar abu 0,98\% menjadi 1,80\%, namun menurunkan kadar air $11,21 \%$ menjadi $10,66 \%$ dan karbohidrat $70,40 \%$ menjadi $60,43 \%$. Saran agar dapat dilanjutkan ke penelitian selanjutnya terkait daya tahan produk.

\section{DAFTAR PUSTAKA}

Apriantono. 1988. Analisis Pangan. ITB. Bandung

Association of Official Analytical Chemist (AOAC). 2005. Official Methode of Analysis. AOAC Arlington.

Mahmud, M.K., N. A. Hermana, I. Zulfianto, R.. R. Ngadiarti, B. Apriantono, Hartati, Bernadus dan Tinexelly. 2008. Tabel Komposisi Pangan Indonesia. PT Elex Media Komputindo. Kompas Gramedia. Jakarta

Mukhsinatunisa, 2013.Analisis Kadar Air dalam Bahan Makanan. http:// mukhsinatunisa.blogspot.cpm/2013/laporan-praktikum-kadara-air.htm.

Ningrum, E.N.1999. Kajian Teknologi Pembuatan Tepung Ubi Jalar Instan Kaya ProVitamin. Skripsi. Fakultas Teknologi Pertanian. IPB.Bogor

Pratama, R.I., Lis R. Yusuf A. 2013. Komposisi Kandungan Senyawa Flavor Ikan Mas dan Hasil Pengukusannya, Fakultas Perikanan dan Ilmu Kelautan. Universitas Padjajaran, Bandung, Jurnal Akuatika. 4(1).

Sudarmadji, S., B. Haryono dan Suhardi. 1997. Prosedur Analisa Bahan Makanan dan Pertanian. Liberty. Yogyakarta 
Sugito, dan Hayati, 2006. Penambahan Daging Ikan dan Aplikasi Pembekuan Pada Pembuatan Pempek Gluten. Jurusan Teknologi Pertanian. Palembang : Universitas Sriwijaya. Jurnal Ilmu-Ilmu Pertanian Indonesia. 8(2).

Sunahwati E. 2000. Studi Karakteristik Arabushi Ikan Cakalang (Katsuwonus pelamis) setelah Proses Fermentasi kapang. [Skripsi] Bogor (ID): Fakultas Perikanan dan Ilmu Kelautan. Institut Pertanian Bogor.

Sofiati T, Asy'ari, Sidin J. 2020. Uji Kadar Protein dan Lemak pada Sagu dengan Penambahan Ikan Cakalang di Kabupaten Pulau Morotai. Jurnal Ilmiah Wahana Pendidikan. 6(2):158-162.

Winarno, F.G. (2008). Kimia Pangan dan Gizi. Gremedia. Jakarta 